\title{
A PESQUISA INTERVENÇÃO COM O CURRÍCULO CULTURAL DE EDUCAÇÃO FÍSICA, SEUS CORPOS E SUAS DANÇAS: TRÊS EXERCÍCIOS CARTOGRÁFICOS
}

\author{
RESEARCH INTERVENTION WITH THE CULTURAL PHYSICAL \\ EDUCATION CURRICULUM, ITS BODIES AND THEIR DANCES: THREE \\ CARTOGRAPHIC EXERCISES
}

\author{
Adriana de Faria Gehres ${ }^{1}$ \\ Marcos Garcia Neira ${ }^{2}$
}

\begin{abstract}
Resumo: Este artigo objtivou cartografar encontros os corpos, as danças e a Educação Física culturalmente orientada, a partir dos pressupostos da esquizoanálise (DELEUZE; GUATTARI, 1996), como pesquisa intervenção. Para tanto, realizamos três exercícios cartográficos como encontros/processos de acionamento de: um texto; quinze relatos de experiência; e ações didáticas. Neste último, contudo, operamos também com a "palavra" experiência, conforme proposto por Larrosa, (2009, 2013, 2018). Cartografar, procedimento, objetivo e texto da pesquisa, apresentou-se como uma "atitude" que nos fez percorrer materialidades, inventar conceitos e produzir línguas nos encontros com o curículo culturalmente orientado de Educação Física.
\end{abstract}

Palavras-chave: Esquizoanálise; Intervenção; Experiência; Escola.

\begin{abstract}
This article aimed to map encounters with bodies, dances and culturally oriented Physical Education, based on the assumptions of schizoanalysis (DELEUZE; GUATTARI, 1996), as intervention research. For this purpose, we carried out three cartographic exercises as meetings / processes for triggering: a text; fifteen experience reports; and didactic actions. In the latter, however, we also operate with the "word" experience, as proposed by Larrosa, $(2009,2013,2018)$. Mapping, procedure, objective and text of the research, presented itself as an "attitude" that made us go through materialities, invent concepts and produce languages in the meetings with the culturally oriented Curriculum of Physical Education.
\end{abstract}

Keywords: Schizoanalysis; Intervention; Experience; School.

\section{Introdução}

O artigo apresenta alguns resultados da investigação que objetivou intervir, inventar, experimentar e criar fatos com o currículo culturalmente orientado em Educação Física (NEIRA, 2019), numa perspectiva não representacional de corpo, linguagem e prática corporal, juntamente, com as práticas corporais e artísticas da dança na contemporaneidade, apontando como o processo de intensificação dos encontros com o

\footnotetext{
${ }^{1}$ Doutora em Motricidade Humana, Faculdade de Motricidade Humana-Universidade de Lisboa (FMHUL). Universidade de Pernambuco (UPE), Recife, PE, Brasil. E-mail: adriana.gehres@upe.br

${ }^{2}$ Livre-Docente em Metodologia do Ensino de Educação Física, Universidade de São Paulo (USP). Universidade de São Paulo (USP), São Paulo, SP, Brasil. E-mail: $\underline{\text { mgneira@ usp.br }}$
} 
currículo cultural da Educação Física, os corpos e as danças tornaram-se a nossa própria pesquisa $^{3}$.

O currículo cultural da Educação Física organizou-se nos estudos de Neira e Nunes $^{4}$, em diálogo com as práticas de professorxs das redes públicas e privadas da Grande São Paulo, através das atividades do Grupo de Pesquisas em Educação Física Escolar (GPEF) da Faculdade de Educação da Universidade de São Paulo (FEUSP).

Resumidamente, Neira e Nunes (2011), Neira $(2011,2019)$ e os participantes do GPEF aproximaram-se, inicialmente, dos estudos culturais e do multiculturalismo crítico para desestabilizar as posturas críticas e acríticas da Educação Física, sobretudo, explodindo com a noção de identidade única, fixa e hegemônica que caracterizara as propostas até então, com vistas a dar a ver as culturas não-hegemônicas na escola, inspirando outras formas de promover intervenções didáticas. Com Bonetto (2017), entre outros, podemos afirmar que, atualmente, os referenciais do currículo cultural em Educação Física têm se expandido para outros ambientes teóricos, sobretudo aqueles denominados de pós-estruturalistas 5 .

Tomamos a Educação Física cultural como um conjunto de ações implementadas por um coletivo de professorxs da Educação Básica que passou a atuar sobre sua própria prática e sobre o próprio currículo cultural, a partir das questões cotidianas e que se aproximavam das teorias curriculares "pós. Como afirma Neira (2019, p. 15):

O currículo de Educação Física tornou-se um campo aberto ao debate, ao encontro de posicionamentos distintos, à mercê de agenciamentos cariados e à confluência da diversidade de práticas corporais. Uma arena de disseminação de sentidos, de polissemia e de produção de identidades voltadas para a análise, significação, questionamento e diálogo entre e a partir das culturas corporais.

\footnotetext{
${ }^{3}$ Os resultados parciais desta pesquisa foram apresentados no Congresso Ibero-Americano de Investigação Qualitativa, 2019, e estão publicados nas Atas CIAIQ 2019, como artigo completo "Exercícios cartográficos com o currículo cultural da Educação Física no Brasil: uma pesquisa intervenção.” Naquela ocasião apresentamos resumidamente e, ainda em fase de elaboração, os resultados parciais da nossa pesquisa sobre corpo, linguagem e dança com o currículo cultural de educação física, com ênfase nos procedimentos da pesquisa intervenção esquizoanalítica (GEHRES; NEIRA, 2019)

4 Embora as produções dos autores tenham se iniciado a partir de 2006, os documentos analisados neste artigo são aqueles produzidos mais recentemente pelos professores e professoras que assumem colocar em ação a perspectiva pós-crítica.

5 Sobre o currículo cultural em Educação Física, Bonetto (2017) vasculhou os seus pressupostos, embrulhou e desembrulhou suas produções, conceitos, princípios ético-políticos e procedimentos, em ações ora de criação, ora de verificação, fazendo-se acompanhar pela geofilosofia de Deleuze e Guattari. Neste processo, o autor debruçou-se sobre o conceito de escrita-currículo e ao escrutiná-lo, compõe-no em: historicidade, assinatura, planos ou campos de imanência, elementos ou componentes, multiplicidades, personagens conceituais, traços de intensidade e objetividade. Outros autores no campo do currículo culturalmente orientado em Educação Física também têm se aproximado dos referenciais pósestruturalistas, como Nunes (2018) e Borges, Vieira e Melo (2017).
} 
Na constante co-constituição do currículo cultural, a linguagem corporal, as práticas corporais e seus corpos, destacam-se como a própria ação política e intencional, afastando-se de uma compreensão da proposta, das práticas corporais e seus corpos como produção linguística representacional.

Tomando a discussão sobre a linguagem numa perspectiva da pragmática deleuzoguattariana, como materialidade pós-estruturalista, evidenciamos que para os autores, a expressão e o conteúdo possuem formas próprias, a forma conteúdo ou lição dos "corpos" $"$ e a forma expressão, a lição dos signos, que agem uma sobre a outra. A função linguagem, assim entendida, opera através da atribuição dos expressos, os enunciados, sobre os conteúdos. Dessa forma, os expressos não representam, comunicam ou informam os conteúdos sentidos ainda que linguisticamente, porque há total independência entre eles. Apesar da presença de uma relação de reciprocidade, o que assistimos é a uma intervenção incessante de um sobre o outro, na transmissão constante de palavras de ordem.

\begin{abstract}
A função-linguagem é transmissão de palavras de ordem, e as palavras de ordem remetem aos agenciamentos, como estes remetem às transformações incorpóreas que constituem as variáveis da função. A linguística não é nada fora da pragmática (semiótica ou política) que define a efetuação da condição da linguagem e o uso dos elementos da língua (DELEUZE; GUATTARI, 1995b, p. 20).
\end{abstract}

Assim, as práticas corporais, com o currículo cultural, podem acionar, a todo o tempo, disputas de significações culturais e sociais com as situações didáticas operando na chave da problematização e da desconstrução das práticas corporais para a produção de mais diferenças, interpelando a fixação de significados, na fabricação de corpos, como processos e não como lócus.

Ao produzir corpos nas aulas culturalmente orientadas, em suas intensidades e multiplicidades, conteúdos (corpos periféricos, menores, piores) e expressos (práticas corporais negras, indígenas, urbanas, infantis), aprofundam a função linguagem das práticas corporais. Ou como afirma Neira (2019, p. 97): "Há que se promover a interação e interdependência entre os saberes de todos os tipos (hegemônicos, contra-hegemônicos, legitimados, marginalizados) para que o conhecimento seja compreendido como intervenção e não como representação".

\footnotetext{
${ }^{6}$ Neste momento do texto, os autores estão se referindo a uma primeira filosofia da linguagem, por eles identificada entre os estoicos. Segundo Deleuze e Guattari (1995b), os estoicos dão a palavra corpo o sentido de ser todo o conteúdo formado.
} 
Essa operação permite, potencialmente, ao conhecimento/linguagem (expresso e conteúdo; práticas corporais e corpos), com o currículo cultural, deixar de ser lócus ou substância, transformando-se em processo incessante de intervir/produzir corpos e práticas corporais, intensidades, multiplicidades e fluxos.

Para além disso, o currículo cultural, na atuação do GPEF, aponta para uma produção em cascata de jogos de linguagem (conteúdos e expressos) em aulas, relatos, dissertações, teses, livros, palestras, discussões e iniciativas de formação continuada que agem sobre o currículo culturalmente orientado, desestabilizando-o constantemente. Vemos emergir um fazer pulsional em que conteúdos e expressos produzem "palavras de ordem" sobre o PRÓPRIO currículo cultural.

Nesse sentido, a investigação realizada caracteriza-se como uma ação/intervenção com/sobre o currículo cultural da Educação Física que teve como objetivo cartografar encontros com a proposta, os corpos e as danças, como pesquisa intervenção esquizoanalítica.

\section{Metodologia}

Mas o que é cartografar? Cartografar é um objetivo de pesquisa ou é o próprio procedimento da pesquisa? Bem, aqui cabe-nos retornar ao ambiente teóricometodológico com o qual dialogamos para produzir nossa questão/objetivo, qual seja: a pragmática deleuze-guattariana que, como metodologia ou, uma não epistemologia, que se propõe a vir a ser, cochicha:

Todo centro de poder tem efetivamente estes três aspectos ou estas três zonas: 1) sua zona de potência, relacionada com os segmentos de uma linha sólida dura; 2) sua zona de indiscernibilidade, relacionada com sua difusão num tecido microfísico; 3) sua zona de impotência, relacionada com os fluxos e quanta que ele só consegue converter, e não controlar nem determinar. (....) O estudo dos perigos em cada linha é o objeto da pragmática ou da esquizoanálise, visto que ela não se propõe a representar, interpretar nem simbolizar, mas apenas a fazer mapas e traçar linhas, marcando suas misturas tanto quanto suas distinções (DELEUZE; GUATTARI, 1996, p. 99-100).

Deleuze e Guattari (1996) seguiram estudando os perigos dessas linhas e inventando conceitos, a tarefa da filosofia, como ato, performance, ação. No Brasil, Guattari e Rolnik (1996) nos aproximam das suas cartografias do desejo de diversas formas. A obra resulta das cartografias dos encontros vividos durante as viagens de Félix Guattari pelo Brasil (cinco estados) e a viagem de produzir o livro (mais de 700 páginas de transcrições). Na ótica dos autores, as cartografias são, sobretudo, dos inconscientes que protestam ou que procuram mover e acionar outros territórios. A obra também seduz 
pelo exercício analítico de criar sentidos, no plural, sem necessariamente querer, fazer-se sentido, na demonstração, representação ou interpretação dos temas propostos. E, por fim, da discussão sobre a esquizoanálise que, como bem identificou Romagnoli (2014), inscreve-se, no Brasil, no campo das discussões em Psi, e nesse caso, nos debates sobre o inconsciente em Freud e o inconsciente na esquizoanálise, destacam como uma cartografia se instaura como um processo singular, complexo e elaborado, como procedimento de pesquisa/intervenção.

Passos, Kastrup e Escóssia (2015) compreendem a cartografia como acompanhamento de processos, destacando seu sentido performático e rizomático, conforme proposto por Deleuze e Guattari (1995a) no primeiro platô, dos mil (rizoma). Os autores propõem uma reversão da noção de método a partir da etimologia da palavra - metá-hódos, que se caracteriza como caminho para alcançar metas já estabelecidas, transformando-o em hódos-metá, ou metas que se constituem no caminho. Para tanto, cartografaram pistas sobre o método, as quais não foram muito exploradas diretamente nessa investigação, ainda que estivessem presentes.

Por fim, temos o trabalho de Ribeiro (2016), que talvez tenha sido aquele que mais nos afetou na aproximação com os filósofos inventores de conceitos. Para a autora, o método, a esquizoanálise ou pragmática e a cartografia, seu procedimento, dar-se-á na produção de uma vontade de verdade no próprio processo de pesquisar. Perguntar e produzir dados instalam-se como agenciamentos de um sobre o outro, como o próprio encontro entre Deleuze e Guattari. No e do encontro emergem os traçados e as linhas de força. "[...] considerar aquilo que usualmente denominamos de método - seja nos domínios científicos, filosóficos ou artísticos - como um trabalho de experimentação de pensamento efeito da imanência dos encontros. Tratar-se-ia de pensar o método como acontecimento" (RIBEIRO, 2016, p. 72).

Dessa forma, o próprio procedimento age sobre o objetivo como palavra de ordem, agenciando-o. Retornando a Romagnoli (2014, p. 46-47), insistimos que a implicação na esquizoanálise se estabelece no "meio" entre sujeito e objeto, dicotomia e separação que esse tipo de pesquisa busca superar, não como conflito desvelado pelos pesquisadores para a geração de consciência e atuação, mas no entendimento de que “... a realidade é abordada por imanência e exterioridade, e o "meio" emerge como a dimensão que sustenta os devires, que vai produzir agenciamentos fazendo eclodir o novo."

No processo de pesquisar, a investigação empreendeu três ações/intervenções com/sobre o currículo cultural que denominamos de exercícios cartográficos. 


\section{Apresentação e discussão de resultados ou dos exercícios cartográficos}

Os exercícios cartográficos foram vividos como encontros com: um capítulo de livro que se apresentou sob a forma de ensaiso crítico para discutir a Educação Física na área das Linguagens e a linguagem corporal no currículo culturalmente orientado de Educação Física; relatos de experiência com danças de membrxs/professorxs da Educação Básica do GPEF; aulas de Educação Física de três professorxs/pesquisadorxs/membrxs do GPEF.

\subsection{Exercício 1 - Disjuntar materialidades textuais ou do intervalo entre A e B}

O primeiro exercício se estabeleceu como uma ação de cartografar um texto, capítulo de um livro, que discute a linguagem corporal na Educação Física e, mais especificamente, no currículo cultural. O texto sofreu duas intervenções: na primeira analisamos a partir de um olhar hermenêutico, talvez o pudéssemos denominar assim, como análise, interpretação, num ambiente de conhecimento como representação (A); e, uma segunda aproximação, como exercício cartográfico, na qual procuramos nos afastar da representação e, principalmente, mergulhamos nos próprios movimentos do texto, num exercício de conhecimento como criação/intervenção/ação (B). No quadro 1 abaixo apresentamos alguns trechos desses dois momentos:

Quadro 1: A - uma análise hermenêutica; B - um procedimento cartográfico ${ }^{7}$

\begin{tabular}{|l|l|}
\hline \multicolumn{1}{|c|}{ A } & \multicolumn{1}{|c|}{ B } \\
\hline $\begin{array}{l}\text { Na literatura sobre currículo cultural, } \\
\text { identificamos apenas um texto específico } \\
\text { produzido por Nunes (2016), versando } \\
\text { diretamente sobre linguagem. }\end{array}$ & $\begin{array}{l}\text { "Educação Física na área de códigos e } \\
\text { linguagens" (Nunes, 2016), está composto, } \\
\text { espacialmente e temporalmente, por dois } \\
\text { discursos sobrepostos. Um primeiro } \\
\text { discurso se instala em seções, com títulos } \\
\text { em itálico (um conto ..., recontando ...., E } \\
\text { depois?, E agora?), de pequenos textos, nos } \\
\text { quais ouvimos, vemos, cheiramos e } \\
\text { sentimos as crianças em ação. Estas seções } \\
\text { aparecem como um refrão, inserindo-se em } \\
\text { diversas partes do texto, num procedimento } \\
\text { compositivo de rondo, com os seus } \\
\text { ritornellos (as vozes das crianças) }{ }^{11 . ~ E s t a s ~}\end{array}$ \\
\hline
\end{tabular}

\footnotetext{
${ }^{7}$ Os trechos da análise hermenêutica aqui apresentados em (A) foram escritos como parte da revisão de literatura do projeto de pesquisa de estágio pós-doutoral submetido à Comissão de Pesquisa da Faculdade de Educação da Faculdade de São Paulo); os excertos do procedimento cartográfico (B) são parte do texto dos resultados da pesquisa de estágio pós-doutoral realizada e disponível no site www.gpef.fe.usp.br)

${ }^{11} \mathrm{O}$ rondo é uma forma fixa de poesia, criada na França, e de composição musical seccionada, estruturada a partir de um tema principal e vários temas secundários (normalmente dois ou três), sempre intercalados pela repetição do tema principal. A forma caraterística é determinada pela parte A, que se repete várias
} 


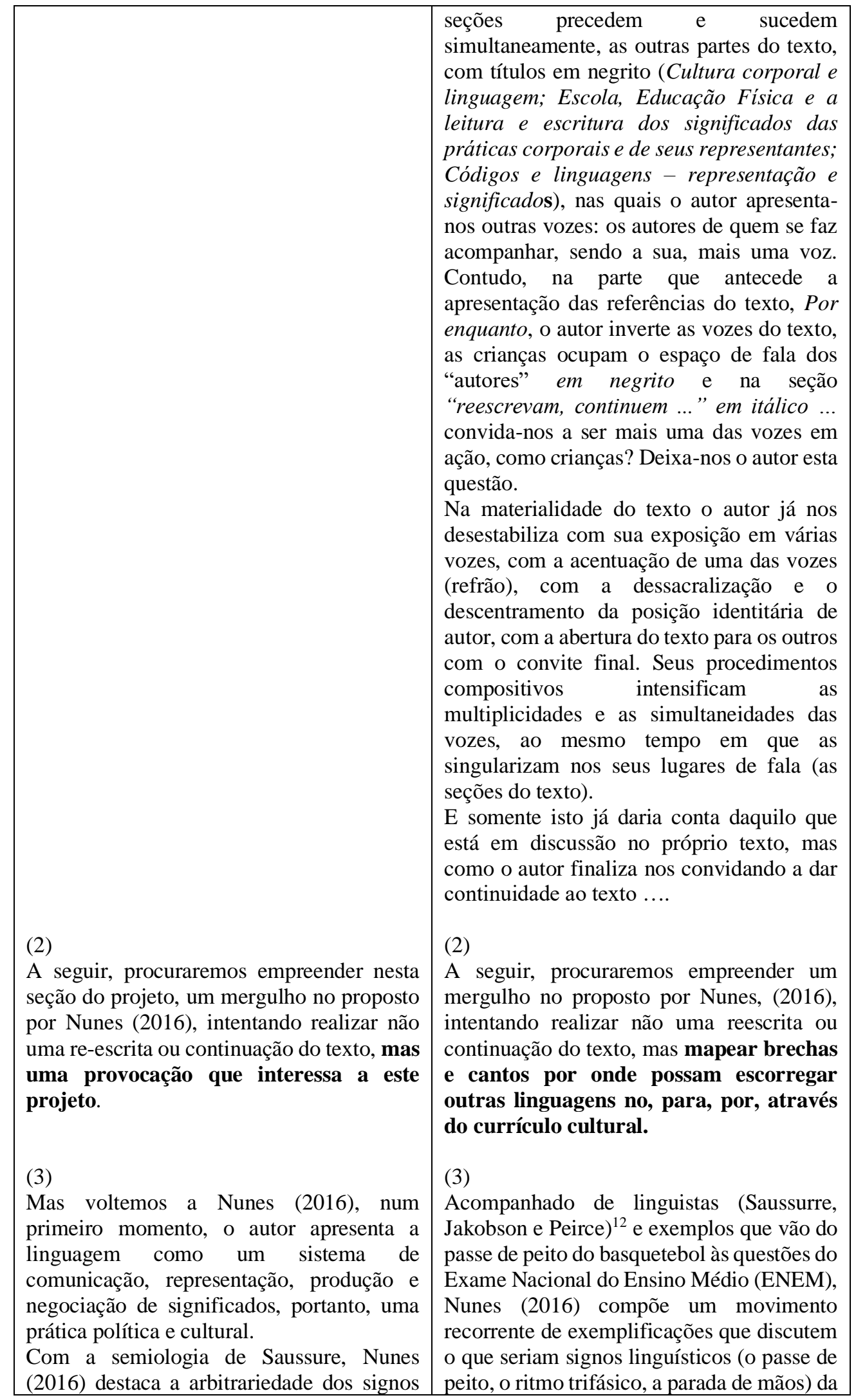

vezes na composição e é chamado também de ritornelo (italiano: ritornello = repetição), e o coupletou episódio, um tipo de estrofe, que cada vez é diferente, gerando desta maneira a forma A - B A - C - A - D - A

12 Charles Sanders Peirce (1839- 1914), filósofo, pedagogo, cientista, linguista e matemático americano. Roman Osipovich Jakobson (1896-1982), pensador e linguista russo. 


linguísticos para informar que os
significados são constituídos em meio a um
sistema de representação. E, com a
Semiótica pierciana ${ }^{8}$, demonstra que todos
os sistemas de informação e comunicação
humanos são linguagens: científica,
matemática, corporal, etc. Assim sendo,
estabelecer uma área específica de
linguagens no processo de escolarização,
como definido nos últimos documentos
orientadores para as práticas escolares no
Brasil (OCN e BNCC nas suas três versões),
não faz nenhum sentido para este autor. E,
mais enfaticamente atesta que esta
classificação no campo da Educação
Física alimenta compreensões
reducionistas e confusas da mesma?.

(4)

Para Nunes (2016), o corpo do currículo cultural da Educação Física é:

... um texto, passível de comunicação, logo, de leitura e escritura (a produção de novas formas de comunicar). Quando o homem se comunica, usa de variados recursos disponíveis a fim de que a intenção de sua ação possa ser compreendida, comunicada. Isso não é diferente na expressão corporal. O corpo todo e todos os elementos a ele agregados são utilizados durante o processo comunicativo. Esses recursos da comunicação corporal compreendem as roupas, os diversos tipos de ornamentos, as marcas que definem o corpo como a altura, a cor da pele, os traços da face, o volume corpóreo, o cabelo, cicatrizes etc., e além desses, os gestos. Todos são textos do corpo. Todos constituem o corpo como um texto, uma forma específica de linguagem, a linguagem corporal (NUNES, 2016, p. 9).

Com Santaella acrescentaríamos os sons e as falas que do corpo emanam, para não ficarmos apenas nos elementos visuais. Contudo, o autor não se limita a identificar a materialidade da mídia e de seus processos sígnicos, no campo das trocas culturais, vejamos:
Educação Física e o entendimento de que outras produções humanas também são sígnicas $^{13}$ (a datação de uma pedra e a de uma árvore, os traços dos mapas, a composição química dos alimentos). Com este procedimento, Nunes (2016) apressa-se em negar veementemente a condição de "exclusividade" de determinadas produções humanas, nomeadamente, as línguas materna ou estrangeira, as artes e as práticas corporais, como linguagens.

Contudo, os exemplos em cascata na produção da negação da Educação Física como "área de conhecimento de linguagens e códigos", produzidos pelo autor, servemlhe apenas para deslocar a Educação Física, como prática pedagógica, da pragmática semiótica de Peirce, para, instalá-la, talvez, numa outra pragmática que lhe/nos interessa mais diretamente, na discussão sobre cultura corporal como linguagem. $\mathbf{O}$ deslocamento emergente da negação, da negação da Educação Física como área de conhecimento Linguagens, produz um efeito de ressonância que irá reverberar em todo o texto.

(...)

(4)

Para Nunes (2016, p. 09), o corpo do currículo cultural em Educação Física é:

.. um texto, passível de comunicação, logo, de leitura e escritura (a produção de novas formas de comunicar). Quando o homem se comunica, usa de variados recursos disponíveis a fim de que a intenção de sua ação possa ser compreendida, comunicada. Isso não é diferente na expressão corporal. O corpo todo e todos os elementos a ele agregados são utilizados durante o processo comunicativo. Esses recursos da comunicação corporal compreendem as roupas, os diversos tipos de ornamentos, as marcas que definem o corpo como a altura, a cor da pele, os traços da face, o volume corpóreo, o cabelo, cicatrizes etc., e além desses, os gestos. Todos são textos do corpo. Todos constituem o corpo como um texto,

8 Pierce propõe uma teoria geral dos signos

9Se permanecermos nessa explicação, também não encontraremos respaldo para afirmar a Educação Física na área de códigos e linguagem. Afinal, poderíamos dizer que se as fórmulas matemáticas, a datação de uma pedra e a de uma árvore, os traços dos mapas, a composição química dos alimentos comunicam algo, poderia se afirmar que a Educação Física também transmite a linguagem das práticas corporais, a linguagem que lhe é específica. Ou seja, ao ensinar o passe de peito, o ritmo trifásico, a parada de mãos, a debicada, o rabo-de-arraia, a dobradiça etc. o professor estaria ensinado uma linguagem e seus códigos específicos. O que, convenhamos, é extremamente superficial e insuficiente para tal inserção. Poderia a Educação Física também ter em seus planos de ensino um eixo de linguagem. Dessa ideia decorre em mais uma confusão na área (NUNES, 2016, p. 4-5).

13 Neste ponto, o autor navega na principal distinção entre as teorias de Saussure e Pierce, de acordo com Santaella (1983), Saussure estabelece uma teoria geral dos signos linguísticos e Pierce uma teoria geral dos signos. 
São os gestos enredados em meio à cultura e seus sistemas de representação que impõem os significados da linguagem corporal. Os gestos, mediante o intercâmbio que estabelecem com a cultura ao longo da vida, vão conformando um estilo pessoal de ser, proporcionando um corpo que se identifica pela sua corporeidade. Por partilhar os significados da gestualidade em um determinado grupo, a linguagem corporal constitui parte da identidade cultural, pois também permite o processo de comunicação entre os pares. Cada cultura propicia uma educação do corpo diferente, que por meio dos gestos a expressa e se identifica (NUNES, 2016, p. 9) (grifo nosso)

Mas, ao posicioná-la, mídia-corpo, no campo das interações sociais e culturais como forma de expressão e identificação cultural, Nunes (2016) reforça as propostas semióticas na apresentação de seus constituintes icônicos (as roupas, os gestos, volume corpóreo, etc.), indiciais (por partilhar significados de gestualidade em um determinado grupo, ser parte da identidade cultural) e simbólicos (a cultura corporal).

Dentre as práticas sociais ou formas culturais de cada grupo encontram-se as práticas corporais com aspectos lúdicos, que são sistematizadas, ressignificadas, hibridizadas e transmitidas de geração a geração em cada grupo cultural. A partir daí é possível identificar a cultura corporal como um campo de luta pelo controle do significado, expressa na intencionalidade comunicativa da gestualidade humana (NEIRA; NUNES, 2006, 2009). Essas práticas sociais corporais são comumente classificadas como esportes, ginásticas, lutas, danças e brincadeiras e suas infinitas e constantes transformações e recriações (NUNES, 2016, p. 9).

Esportes, ginásticas, lutas, danças e brincadeiras, entendidos como práticas corporais e culturais, ainda que ressignificadas e hibridizadas, são entendidas como símbolos, porque são gerais e abstratos, manifestam-se em réplicas, ocorrências singulares e contêm elementos icônicos e indiciais (SANTAELLA, 1983).

Como pode ser observado acima, o autor uma forma específica de linguagem, a linguagem corporal.

Com Santaella $(2007)^{14}$, acrescentaríamos os sons e as falas que do corpo emanam, para não ficarmos apenas nos elementos visuais. Neste movimento o autor instala a materialidade da mídia e seus processos sígnicos e os instala no campo das trocas culturais, como muito bem fez Peirce, vejamos:

São os gestos enredados em meio à cultura e seus sistemas de representação que impõem os significados da linguagem corporal. Os gestos, mediante o intercâmbio que estabelecem com a cultura ao longo da vida, vão conformando um estilo pessoal de ser, proporcionando um corpo que se identifica pela sua corporeidade. Por partilhar os significados da gestualidade em um determinado grupo, a linguagem corporal constitui parte da identidade cultural, pois também permite o processo de comunicação entre os pares. Cada cultura propicia uma educação do corpo diferente, que por meio dos gestos a expressa e se identifica (NUNES, 2016, p. 9) (grifo nosso)

Ao posicionar, mídia-corpo, no campo das interações sociais e culturais como forma de expressão e identificação cultural, Nunes (2016) apresenta seus constituintes icônicos (as roupas, os gestos, volume corpóreo, etc.), indiciais (por partilhar significados de gestualidade em um determinado grupo, ser parte da identidade cultural) e simbólicos (a cultura corporal). ${ }^{15}$

Dentre as práticas sociais ou formas culturais de cada grupo, encontram-se as práticas corporais com aspectos lúdicos, que são sistematizadas, ressignificadas, hibridizadas e transmitidas de geração à geração em cada grupo cultural. A partir daí, é possível identificar a cultura corporal como um campo de luta pelo controle do significado, expressa na intencionalidade comunicativa da gestualidade humana (NEIRA; NUNES, 2006, 2009). Essas práticas sociais corporais são comumente classificadas como esportes, ginásticas, lutas, danças e brincadeiras e suas infinitas e constantes transformações e recriações (NUNES, 2016, p. 9).

\footnotetext{
${ }^{14}$ Santaella (2007) irá estabelecer uma teoria geral das matrizes sígnicas, na medida em que nos demonstra que, embora os séculos XIX, XX e XXI tenham assistido a uma multiplicação das mídias de produção de linguagens, “ ".. há apenas três matrizes lógicas, a partir das quais, por processos de combinações e misturas originam-se todas as formas possíveis de linguagem e processos de comunicação. Essas matrizes são: a sonora, a visual e a verbal" (SANTAELLA, 2007, p. 76). Contudo, a infinitude de mídias nos processos sígnicos, contém também especificidades, na medida em que há “... inseparabilidade dos processos de signos em relação aos meios em que tomam corpo...” (SANTAELLA, 2007, p.82)

${ }^{15}$ Sobre isto ver a primeireidade, a segundeidade e terceireidade na semiótica pierciana (SANTAELLA, 1983).
} 


retorna sempre às ações de semanticidade
e semioticidade (corpo como mídia que
atribui e constitui significados), das quais
pretendeu se afastar na crítica que fez à
semiologia e à semiótica. Esta operação
pode ser observada também nos inúmeros
relatos apresentados pelo GPEF.
relatos apresentados pelo GPEF. ${ }^{10}$
Esportes, ginásticas, lutas, danças e brincadeiras, entendidos como práticas corporais e culturais, ressignificadas e hibridizadas, são entendidas como símbolos, porque são gerais e abstratos, manifestam-se em réplicas, ocorrências singulares e contêm elementos icônicos e indiciais. (SANTAELLA, 1983).

Contudo, a linguagem corporal, instalada como signo, é convidada por Nunes (2016, p. 09) a tornar-se ainda mais movente, mas sobretudo, política, quando se aproxima dos estudos pós-estruturalistas e assim inicia:

Os estudos da semiótica parecem limitar o processo de linguagem e da representação ao tratá-lo como um sistema fechado, concebido no ato de sua significação. $\mathrm{O}$ que faz crer que um sistema de representação está fadado para ser sempre aquilo que lhe foi significado. $O$ pensamento pósestruturalista reconhece a natureza interpretativa da cultura e do fato de que interpretações nunca produzem um momento final da verdade absoluta. Para este, as interpretações são sempre seguidas de outras interpretações, numa cadeia sem fim. Os estudos pós-estruturalistas têm dado mais atenção à representação como fonte de produção de conhecimento social, um sistema mais aberto e ligado às práticas sociais e às questões de poder.

Por dentro da própria pragmática semiótica, na reciprocidade das mídias e dos fluxos sígnicos e das relações de poder, Nunes (2016) produz vibrações na cultura corporal, ao apresentar a "representação" como produção, e não como comunicação ou informação de conhecimentos, conhecimento social que se instala e reinstala-se constantemente mediante as lutas sociais, culturais e, em última instância, políticas, porque são atos de poder. Neste caminho, apresenta-nos as proposições de Foucault e Derrida. Do primeiro ressalta o discurso mídia/signo e suas condições de produção como conhecimento em seus arranjos sociais, culturais e políticos.

"O conhecimento ligado ao poder não só assume a autoridade de ser a verdade, mas uma vez aplicado no mundo real, produz efeitos reais e, nesse sentido, torna-se verdadeiro" (NUNES, 2016, p. 18).

Com Derrida, enfatiza as operações de significação que procuram fixar signos na escamoteação dos seus diferentes, num processo constante de vir a ser, e nesse

10 http://www.gpef.fe.usp.br/index.php/relatos-de-experiencia/ 
(5)

Tedesco \& Valviesse (2009), como Nunes (2016), estabelecem a mesma crítica à semanticidade da semiologia, quando afirmam: "Ao isolar a linguagem do mundo dos fatos, define-se de modo insuficiente o sentido, excluindo dele sua potência de intervenção na realidade" (TEDESCO; VALVIESSE, 2009, p. 4). Contudo, as autoras se acercam da pragmática de Deleuze \& Guatari (1996) para potencializar a dimensão intensiva da linguagem.

Tedesco, \& Valviesse, (2009) ressaltam dois aspectos que nos interessam para a linguagem corporal no currículo cultural. $\mathrm{O}$ primeiro consubstancia-se na reciprocidade e na simultaneidade dos aspectos linguísticos (os códigos) e extralinguísticos (a produção de sentido) da linguagem, a palavra de ordem, na superação da semanticidade identificada anteriormente.

$$
\text { (...) }
$$

Entretanto, como ressaltado, por nós, inicialmente, o plano da expressão contém uma forma própria que se impõe como ação sobre o conteúdo, não se limitando a representá-lo, comunicá-lo ou informá-lo.

Esta forma própria refere-se aos elementos não linguísticos da linguagem, os incorporais dos estóicos, que a produzem como ato de criação, intensidade que fustiga a representação, na apresentação da função linguagem como acontecimento.

(...)

Com os incorpais propostos por Deleuze \& Guattari (1995b), a partir de Tedesco \& Valdiesse (2009), iniciamos o nosso percurso de análise da linguagem corporal no currículo cultural, identificando, nas transformações incorporais, que são próprias da forma da expressão (os sistemas sígnicos), no caso da Educação Física, as práticas corporais, a subversão da representação para ancorar a diferenciação. Os incorporais (forma própria da expressão) dos corpos (conteúdos) nas práticas corporais, forjam a função sentido, um signo nunca é completo, está sempre em processo.

A discussão apresentada até aqui, fundamenta a concepção de que as práticas da cultura corporal, enquanto textos, inscrevem a história e a trajetória dos grupos culturais e seus representantes. Todavia, a interpretação desses códigos limita-se àqueles que dispõem de certos elementos próprios assimilados na convivência com aquela cultura, pois eles são constituídos de significados. Isto explica a dificuldade para compreender as ideias e motivações características de cada prática corporal e seu grupo representativo. Ao se deparar com outra cultura, tende-se a atribuir ao que se vê os significados estabelecidos na própria cultura. Por conta disso, em alguns casos, estabelece-se o preconceito em relação às posturas, falas, ideias e gestos corporais de outros grupos. $\mathrm{O}$ que, em geral, acaba por produzir significações distantes da intencionalidade produzida (NUNES, 2016, p. 18) (grifo nosso)

No encontro de culturas, as diferenças e os regimes de verdade se evidenciam para desestabilizar as práticas corporais como sistemas fechados transportadores de significações fixas e "hereditárias". Novamente, num bate/rebate entre argumentações e cenas cotidianas, $o$ autor vai alinhavando a linguagem corporal no currículo cultural como um plano móvel que instala temporalidades e espacialidades divergentes e ativas nas bravatas de poder.

(5)

Neste primeiro exercício de cartografar, ainda que timidamente, a linguagem corporal no currículo cultural, por entre o texto de Nunes (2016), procuramos produzir trilhas intrigantes e esperemos que instigantes, na composição material do texto em rondo; na inversão de vozes e papéis; no deslocamento da negação da negação da Educação Física como área de conhecimento das linguagens; mas sobretudo, na ressonância dos movimentos de afastamentos (a ênfase na semanticidade da representação) e aproximações (a discussão sobre o poder) que este autor vem produzindo com o pósestruturalismo.

Como Deleuze \& Guattari (2003), que viajaram por entre as portas, personagens e obras de Kafka, na produção de uma literatura menor, percorremos o texto de Nunes (2016), produzindo uma cultura corporal como linguagem menor, na qual não se pretende interpretar, analisar ou estabilizar conceitos, mas suspender/dilatar tempos e espaços para que outras vozes e traçados 
Nas duas propostas apresentadas (Quadro 1), análise/interpretação hermenêutica (A) e exercício cartográfico (B), o texto é abordado de formas distintas.

$\mathrm{Na}$ análise (A), o texto é um objeto, que veicula e materializa um conceito ou uma ideia (A1). Nos propomos a interpretar ou a provocar essa ideia (A2). Na análise hermenêutica destacamos a posição e as críticas do autor a um certo entendimento de linguagem (semântica e reducionista) e da Educação Física como linguagem (A3). Entretanto, quando da apresentação das noções do autor sobre a linguagem corporal no currículo cultural, apontamos as inconsistências e recorrências da própria semanticidade substantiva que o autor criticou anteriormente (A4). Por fim, propusemos uma outra noção de linguagem, tomando como referência a pragmática política de Deleuze e Guattari (A5), a qual já se apresentava como uma espécie de teoria de referência para analisar o objeto, qual seja, a linguagem no currículo cultural.

O exercício cartográfico (B) difere qualitativamente da análise hermenêutica porque considera o texto em sua materialidade, sua forma conteúdo (a lição dos corpos ou do corpo do texto e a textura das partes que o compõem) e sua forma expressão (lição dos signos ou das significações que vão se projetando no texto) (B1); propõe-se a mapear os movimentos do texto (conteúdos e expressos), traçando trilhas com brechas e rachaduras por onde o texto pode escorregar (B2); com o detector sísmico, a relação da Educação Física com uma certa noção de linguagem se estabelece como uma caixa de ressonância de negação da negação (B3); abrindo caminhos que nos levarão a ações de aproximação e afastamento das pragmáticas pós-estruturalistas (B4); e, por fim, percorre o texto, tectonizando-o como ação/intervenção na produção do próprio texto (B5).

O que emerge entre A e B? Quais os efeitos provocados? Exercício cartográfico 2.

\subsection{Exercício 2 - Acionar relatos de experiência ou da invenção dos conceitos}

O segundo exercício cartográfico foi produzido no encontro com relatos das experiências de tematização da dança amplamente divulgados no site do grupo (www.gpef.com.br). Quinze relatos foram selecionados, lidos, re-lidos, movimentados, acionados. Do encontro com as materialidades dos relatos (como foram escritos, partes constituintes, movimentos de aproximação e afastamento, caixas de ressonância, produção de linguagens corporais menores, etc.), emergiu um outro elemento nos 
procedimentos de pesquisa intervenção: a invenção de conceitos. Como afirma Ribeiro (2016, p. 72): "Uma criação conceitual deriva da afirmação da imanência do encontro, esse agenciamento constituído por toda a tragicidade inerente às suas contingências e limites."

A imanência do encontro com os relatos, nos atos de ler e reler, permitiu indicar linhas e planos, registrando suas combinações e diferenças ${ }^{16}$. Nesse processo, corpos a compor entre os projetos institucionais e as personagens comunitárias; corpos a multiplicar entre esporte, brincadeira, ginástica, dança, masculino, feminino, trans, urbano, rural, profano, sagrado, negro, índio; corpos a intensificar entre o tambor, o smartphone e o alto-falante, foram agenciados sobre o "plano de ensino" com o currículo cultural.

Os relatos produziram, em cascata, corpos comunitários, periféricos, ancestrais, urbanos, nordestinos, rurais, negros, brancos, pardos, amarelos, trans, masculinos, femininos no desfazimento de seus próprios corpos/conhecimentos/conteúdos ou na possibilidade de serem corpos tran(sitórios), virtuais na medida em que se deixam "piorar" quando falam em público, ainda que sejam tímidos, leem textos que não conhecem, riem dos colegas e de si mesmos, silenciam para ver o outro apresentar, observam os instrumentos e as vestes, ouvem músicas, assistem a vídeos, imitam gestos, compõem coreografias, ensaiam apresentações orais, vêem espetáculos, ouvem relatos de pessoas da comunidade escolar.

O exercício cartográfico proposto não demonstrou, verificou, compreendeu ou categorizou os corpos das danças com o currículo cultural, mas sim mapeou territórios e linhas de força que se instalam sobre o "plano de ensino"17, nas ações de compor, multiplicar e intensificar (os conceitos inventados). Estes não são categorias ontológicas do currículo cultural produzido nas escolas, nem teleologias do currículo culturalmente orientado da Educação Física, mas ações que emergem do fundo do "plano de ensino",

\footnotetext{
${ }^{16}$ Esse exercício completo, apresentado como um capítulo de nosso relatório de estágio pós-doutoral que está disponível na página do GPEF (www.gpef.com.br) foi também submetido para publicação como artigo a uma revista da área de educação, mas encontra-se ainda em fase de avaliação.

17 Lapoujade (2015, p. 38), sobre a questão dos fundamentos no pensamento de Deleuze e Guattari: É preciso construir um plano de imanência para o pensamento pois ele efetua suas operações a partir dele e sobre ele, inclusive quando produz transcendências que dele se destacam; assim como é preciso um plano de consistência para a Natureza, pois é a partir dele, sobre ele que ela se produz. É preciso um plano de imagens em si para o cinema que constrói a partir dele, sobre ele, suas dramatizações de espaços-tempos. É preciso um plano de univocidade para as maneiras de dizer do Ser, tanto quanto para a infinita variedade de seus modos de expressão. É preciso um plano de composição a partir do qual e sobre o qual a arte erige seus monumentos. É preciso um plano de referência a partir do qual a ciência distribui suas funções. Na verdade, os planos são por direito inumeráveis pois devem ser construídos a cada vez.
} 
efetuadas a partir dele e sobre ele, com as danças e os corpos relatados. Elas movem os corpos das danças com o currículo cultural como corpos interventivos, menores, desestabilizadores, intervalares, virtuais e relacionais.

Como afirma Lapoujade (2015, p. 37) no campo da geofilosofia de Deleuze e Guattari:

\begin{abstract}
Com efeito, o que é um plano? É uma espécie de corte, uma secção de semfundo destinada a acolher no plano tudo o que dele provém, e não a mergulhar tudo novamente nas profundezas. Ele não se confunde nem com um abismo indiferenciado do qual ainda não sai nada, nem com um mundo diferenciado de onde tudo já saiu, já se distinguiu. Ele reside inteiramente no intervalo entre $o$ indistinto e o distinto, na passagem de um ao outro: é o que se distingue. Nem indeterminado, nem determinado, é $a$ própria determinação. Essa é justamente a definição do plano: a existência autônoma de uma superfície que exprime o que sobe do fundo, à maneira de um crivo ou de um filtro, onde a determinação se faz.
\end{abstract}

No "plano de ensino" com os relatos de experiência com as danças do currículo culturamente orientado da Educação Física, emergiram os conceitos/ações de compor, multiplicar e intensificar corpos e danças, como um encantamento onde a determinação vai se processando.

E no nosso encontro com professorxs, pesquisadorxs, alunxs, escolas e cotidianos entreteceu-se o nosso terceiro exercício cartográfico como criação de línguas para dar materialidade aos conceitos/ações inventados.

\title{
3.3 Exercício 3 - Produzir encontros com o cotidiano escolar ou da invenção das línguas da experiência
}

O terceiro exercício cartográfico foi produzido na materialidade de uma trama imanente na vivência juntamente com três outros docentes do GPEF, em três escolas do município de São Paulo. Para cartografar processos, como atitude e procedimento, inventamos línguas. As três instituições são completamente distintas. A primeira se caracteriza como uma escola de bairro de Ensino Fundamental da rede municipal de São Paulo, neste artigo identificada por EMEF. A segunda é uma escola-laboratório de Ensino Fundamental e Médio vinculada a uma universidade pública paulista, identificada por EFM. A outra escola pertence à rede municipal paulista e se dedica à Educação de Jovens e Adultos, identificada por EJA.

Esses encontros foram vividos como experiência. Esta diverge do experimento porque é singular e não universal; a experiência é única e não pode ser dogmática; e a experiência nunca pode ser pensada a partir da prática, mas sim da paixão (LARROSA, 
2018). Esse caminho evita fazer da experiência um conceito, para não entendê-la a partir do que é, mas como do que acontece, qual o efeito, a mantê-la como palavra e não como conceito, porque o conceito diz o que diz e só, a palavra diz o que diz e algo mais, os conceitos determinam o real e as palavras abrem o real (LARROSA, 2009, 2013). Por fim, temos que evitar fazer da experiência um imperativo, um fetiche.

Na produção da experiência como palavra e acontecimento, as línguas foram dando materialidade textual à singularidade dos encontros em cada uma das escolas para a criação de conceitos/ações.

\section{A língua das imagens}

Os encontros-experiências-acontecimentos na EMEF de um bairro paulistano foram vividos sempre às quintas-feiras a cada quinze dias, no período de agosto a novembro de 2018. Eram seguidos de conversas por whatsapp, mas principalmente por textos escritos e re-escritos. Desde o início, um elemento chamou a atenção: a presença de imagens de danças que habitavam as aulas através de telas de celulares ou mesmo através dos corpos de diferentes pessoas, quase como um outro corpo. Essa presença marcante provocou a colocação de imagens em tela e, assim, a cartografia se apresentou numa línguagem de cenas-aula, cenas-texto e cenas de pós-produção ${ }^{18}$.

As cenas-aula se caracterizam pela apresentação de momentos das aulas que podem constituir-se em descrições, fotografias e/ou diálogos captados em áudio e transcritos, conforme se observa no quadro 2.

Quadro 2: Extratos das cenas-aula

Cena-aula 1: Professor apresenta inúmeros vídeos de pessoas dançando em diferentes ambientes e situações.

Cena-aula 2

$18 \mathrm{Na}$ produção de um evento, artístico, cultural, esportivo, outros, denominamos de pré-produção tudo que antecede a realização do evento e pós-produção o processo desmontagem e avaliação do mesmo. Estamos denominando de cena-pós-produção, os textos que se efetivaram como uma apreciação/avaliação da experiência com as cenas-aula e as cenas-texto, considerando que as mesmas são o próprio evento e que tudo que antecedeu a escrita das mesmas (o objeto, as discussões sobre corpo, dança, Educação Física e as propostas pedagógicas e artísticas em dança, e os exercícios cartográficos anteriores, como todo o processo de pré-produção). 


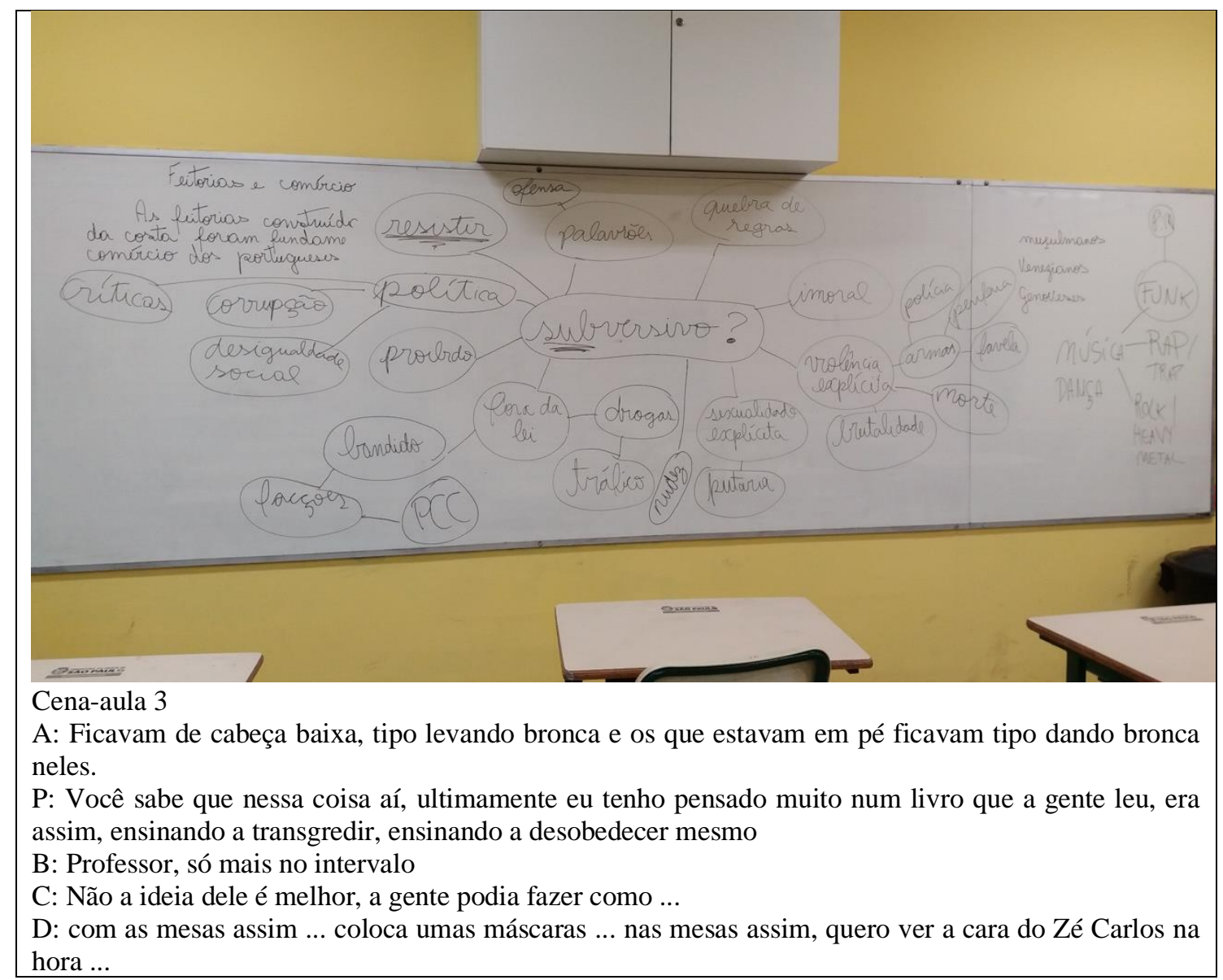

Fonte: Adaptado de Gehres (2019)

As cenas-texto foram produzidas ao longo de todo o segundo semestre de 2018 através de textos de mensagens de whatsapp trocadas entre a pesquisadora e o professor ou textos que eram escritos pela pesquisadora ao final dos encontros, enviados para o professor que comentava, debatia, aproxima-se ou afastava-se do escrito e novamente enviados para pesquisadora que, eventualmente, voltava a escrever sobre o tema ou dava continuidade a partir dos encontros seguintes. Esses textos foram posteriormente transformados em textos únicos, dessasujeitados e produzidos como um dos elementos da língua desses encontros na EMEF, cenas-texto, como pode ser observado no excerto abaixo:

Cena-texto 4: A classificação da Darido ${ }^{19}$ para as danças é aquela que você está querendo e bem, fugir, uma noção de cultura reduzida a território geográfico: danças da comunidade, do estado, do Brasil e do mundo. É esta que vemos na BNCC e está lá desde as primeiras versões. Concordo que temos que ter cuidado com as classificações e por isso já estou falando de campos de significação e que eles são instáveis e móveis. A questão é como fabular e singularizar entendendo estes campos como campos de forças e na escola colocamos todos eles para mexer. Quando você fala dos elementos de

19 Darido, refere-se a professora Suraya Darido que participou do processo de construção da Base Nacional Comum Curricular (BNCC) nas suas três versões. Como a BNCC propõe uma classificação das danças do ponto de vista geográfico, relacionamos a professora Darido a esta classificação. 
ancoragem das danças, você está falando destes campos de significação e destas forças que estão lá nos "expressos" que são as danças, mas eles são fabuláveis e isso é criação, não somatório. Repito que alguns elementos foram observados por você, pela sua experiência com a dança. Mas não me tocam, ou não tocam xs estudantxs, ou não fizeram vibrar, justamente porque partimos de pontos de vista diferentes, referenciais de observação diferentes. Daí extraio a tematização, como algo daquilo que é tema, que nos toca, professor e aluno. Ainda assim arbitrário, provisório. Poderia ser futebol e a participação dos povos americanos nas copas do mundo, mas não. Foi futebol e o evento da copa, a Rússia, o álbum de figurinhas, a hemeroteca. Tudo arbitrário, mas imanente da experiência não como categoria, não como eixo pré-concebido. Por exemplo, penso que é possível tematizar danças sem pensar se o movimento é criado ou repetido, se é coreografia ou improviso, se é para festa ou para aula, se é religioso ou pagão, se é brasileiro ou gringo. Tudo é escolha! Política! O vídeo é só suporte! Mas entendo quando destaca que isso é importante.

Por fim, as cenas de pós-produção foram compostas por reflexões estabelecidas pela pesquisadora a partir de seus encontros-experiência com o professor, estudantes e a escola atravessada pelo seu objeto inicial de pesquisa: a linguagem corporal, os corpos e as danças no currículo culturalmente orientado da Educação Física e os possíveis acionamentos propostos pela produção acadêmica sobre dança, corpo e seu ensino na contemporneidade. Assim, as cenas de pós-produção marcaram um encontro-experiênca também com essa produção, como pode ser identificado no quadro 3:

Quadro 3: Cena pós-produção referente ao encontro com o $7^{\circ}$ ano Cena-pós-produção: O PLANO DA COISA?

[...] já não há significação certa e, na ausência de quaisquer mensagens estáveis, as 'leituras' (se é que se trate disso) e percepções passam a ocorrer pelo contato indiscriminado com as diversas materialidades que se alternam na composição física dos elementos, ou pelas massas sonora e visual que se apresentam muito mais como construções abstratas do que como narrativas configurando histórias. Nesses casos, os aspectos performativos, ou o que efetivamente se concretizaria como fenômeno físico e material, tornam-se preponderantes, fontes primordiais de relacionamento com o receptor e de estímulos visual, áudio-táctil ou odorífico para que este reconstrua por si alguma integridade naquela obra indiscernível pela via racional (RAMOS, 2015 , p. 31)

Performance tem memória? Como se instala e desinstala uma performance? Performances se repetem? Como foi a apresentação da performance? O que há de estabilidade na imobilidade e no processo? Divirtam-se!!!

Agora focada nos significantes imediatos demanda sempre uma disposição espaço-temporal para se impor. É neste lugar e nesse tempo partilhados entre obra e observador que se trama, cada vez mais intensamente, uma sintaxe lúdica entre eles, um jogo de aproximações e distanciamentos, de deslocamentos enfim, no espaço e no tempo, que não constroem finais, mas constituem materialidades provisórias (RAMOS, 2015, p. 63)

Todo o processo de construção do trabalho do $7^{\circ}$ ano foi vivido como ato performativo. Relutância, redundância, ressonância. Desde o tema surgido da vivência da prática da dança, a partir dos vídeos, da música, da discussão sobre subversão, até a apresentação final, as ações procuraram operar 
como mimesis performativa, ação sem narração, numa dinâmica entre mythos (trama, enredo) e opsis (espetáculo), na qual o primeiro desvanece-se na materialidade dos elementos da cena (RAMOS, 2015).

Fonte: Adaptado de Gehres (2019)

A materialidade das imagens em cenas inventou os conceitos de planos de re-encenação (arquivo), do fantasma e da coisa, ativados pelos encontros com a produção, sobretudo de Lepecki (2013) e Ramos (2015).

\section{A língua das histórias}

Após algumas semanas de imersão nas aulas de um professor na EFM, percebemos que o acontecimento-encontro-experiência existia no sentido de agenciamento, talvez, quando conversávamos: professor, pesquisadora, alunxs, antes, durante e após as aulas. Assim, passamos a registrar em áudio e, algumas vezes, em vídeo essas conversas. E do encontro com as transcrições e imagens identificamos que uma língua muito próxima dos contadores de história era confecionada. E assim produzimos pequenas histórias que pretendemos abertas, plurais, intensas, corporais e dessasujeitadas ${ }^{20}$. No fragmento a seguir temos a história das matrizes, das origens, das multiplicidades, das processualidades, da diápora e da violência das danças vividas nas aulas de Educação Física com o $7^{\circ}$ ano.

[...]matriz, [...] um ponto central que dá ideia desse ponto central vai espalhar tudo [...] as atividades, [...] mostra o vídeo do jongo e aí mostra um vídeo de samba rock e tenta ver o que um dialoga com o outro ou se não dialoga, como dialoga, a matriz pode ser ou é africana ou afro-brasileira ou afro-americana ou dependente da origem, e como é que essas danças se interrelacionam, partindo de rock pro funk ...

E aí a gente percebe que

[...] desde a época que a gente começou a falar até agora que [...] a maioria desse tipo de dança são bem igualzinho entre si, apesar das diferenças, parece que todos eles foram criados mas vieram tipo de umaaa coisa só, tipo assim, como se fosse uma, tipo assim, que nem a gente faz uma, não sei, uma árvore genealógica, mas tipo assim ... dá impressão que é uma coisa, mas tem diferentes tipos de dança que traz alguma semelhança entre outros, então dá a impressão que todos eles vieram de uma coisa só ..

\footnotetext{
${ }^{20}$ Nossas histórias apenas apresentavam autores quando se referia a textos já publicados por autores lidos e tomados como parceiros nessa pesquisa
} 
Quando a gente fala numa matriz afro, a gente fica idealizando um negro, mas a gente também não pode pensar nisso, tem vários e a gente vai na multiplicidade das danças você vai ver vários corpos [...]

Há uma distinção entre pensar corpo, imagem, realidade, eu e o outro como coisas substantivas ou como processos. Pensar processualmente implica pensar em algo enquanto está se produzindo. Autores como William James e Gilbert Simondon, em lugares e épocas distintas, afirmaram que aquilo que existe não se refere a coisas feitas, mas a coisas se fazendo - sejam estas coisas corpos, indivíduos, imagens ou ideias. As ideias são produzidas e, ao mesmo tempo, a mente é produzida através delas em um continuum entre corpo e ambiente (GREINER, 2017, p. 41).

[...] aquela coisa do espaço, do ambiente que muda e aí foi que me deu a ideia da diáspora, [...] essa ideia do corpo ambiente, da violência, [...] é um ambiente hostil, não é hostil, como é que você chega no tempo urbano, o jongo é uma dança urbana?

[...] diáspora, violência, [...]dança e ambiente, corpo e ambiente.

[...]desestabilizar a tranquilidade [...] trazer tipo como é que aconteceu, onde aconteceu, acontecia lá no fundo [...] porque não era tranquilo, o cara mandava recado pro outro, olha a gente vai organizar uma fuga aí seu senhor deixa eu ir pra festa [...] aí o cara mandava assim ...

\section{SOM DE ATABAQUE}

Ô com tanto pau no mato, imbaúba é coroné, imbaúba é coroné, ôoooo com tanto pau no mato imbaúba é coroné, repete, prá avisá o outro filho da puta

[...] e será que essa violência também não tá nessas danças urbanas?

[...] a diáspora [...] a gente começou aqui no jazz passou nas dança urbanass, jazz, [...] ]eles acabaram trazendo uma ideia tipo romantizada vamo dizer assim, porque a ideia foi trazer a coisa da gangue, eles não sacaram que os caras tavam pintados, o West Side Story, não sacaram que os caras tavam pintados, com a pele mais escura, caramba o lance do Michael Jackson, no auge, não sacaram isso, eles sacaram o jazz. que é o jazz da academia, o jazz de produto e trouxeram mais o break, o popping, a coisa do hip hop, que eu não sei como vai acontecer amanhã e na semana que vem, o que eles estão representando, o que eles estão trazendo como jongo agora

A língua das histórias, foi inventando seus próprios conceitos: corpoambiente ${ }^{21}$, presença. Vejamos:

\footnotetext{
${ }^{21}$ Embora possamos identificar essa discussão sobre a relação de corpo e ambiente nos estudos de Katz e Greiner $(2005,2008)$ sobre corpomídia, entendemos que aqui ele se produz singularmente com o currículo cultural de Educação Física
} 
Essa ideia de dança contexto nessa perspectiva que eu tou tentando trabalhar se transforma em corpoambiente, é uma perspectiva de corpoambiente porque eu entendo que ... quando eu penso em dança e contexto parece duas coisas prontas, corpo ambiente é uma coisa sempre em processo ...

Então é assim, nessa ideia de ambiente, de ambientação ... não sei se é exatamente isso

ambiente ... ambiente mesmo da dança ...

Então vem prá mim o hip hop, porque eu tenho muito contato com o povo do hip hop que é aquela construção do Largo São Bento ...

Pois é, o próprio ambiente cria o corpo e o corpo cria o ambiente ... o largo são bento não é o mesmo depois do movimento hip hop ...

mas ele continua sendo ... porque na verdade .. ele não continua mais sendo o largo de são bento que era na década de oitenta, final da década de setenta, oitenta ... porque o espaço do metrô foi ajustado de outra maneira, porque o metrô achou que aquilo não devia rolar ali, mas naquela época, o espaço do metrô propiciava, o que eu digo aquele contexto deles, de se encontrar prá dançar, aquele contexto produziu o hip hop ...

Produziu corpos, mas então criou aqueles corpos naquele ambiente e depois eles foram para outros ambientes e criam outros corposambientes, é uma sutil diferença, mas a gente sai de coisas mais fechadas e prontas, até nessa ideia de identidade ... prá uma ideia mais de processo, é uma coisa ativa, é uma coisa ativa, é essa ideia de eu tirar a potência fechando ... de trabalhar nessa ideia de ambiente ... é que isso está ficando mais claro para mim também agora, nas aulas .. vai o que que muda, sei lá, qual é ... porque é tudo muito perto, uma coisa da outra, mas muda ligeiramente a maneira de olhar, de falar e de fazer ... que aciona ali um corpo da presença, um corpo do jogar, esse basquete verdadeiro, né, entrou pela história da capoeira, a história da capoeira, aciona um determinado corpo, um corpo da capoeira, que num determinado momento era um corpo marginal. Porque se ve for pensar no contexto corporal, era um corpo marginal e por isso a figura do Madame Satã ....

\section{A língua das performances ${ }^{22}$}

\footnotetext{
${ }^{22}$ Performance entendida como todo ato de intervenção presente na noção de linguagem como intervenção, mas que encontra seu ápice na performance artística, processo de invenção/intervenção.
} 
Todo o processo de estar na EJA foi permeado por sensações de incompletude tão intensas que beiravam a perplexidade. $\mathrm{O}$ cotidiano da escola deslocava-nos de nossa existência de professora-pesquisadora, ao mesmo tempo, em que ao aguçar a nossa estranheza, não nos cristalizávamos como a outra. Os momentos de ir e vir à EJA, ser profundamente e deixar de ser, criaram um estado de permeabilidade como um estado que denominamos "bactéria".

Os processos-intervenções com a EJA foram produzidos em três performances bactéria: 1) um diálogo entre bactérias; 2) uma performance que se caracterizou como a visita de uma bactéria à EJA; 3) e, por fim, como um exercício ficcional de criação de uma performance com a professora, xs estudantes e a EJA.

O diálogo entre as bactérias se apresentou como uma conversa entre "hecceidades" 23 . Assim, no entendimento da bactéria como "palavra" 24 , os encontros foram narrados por duas bactérias, espirilo e espiroqueta ${ }^{25}$, em estado constante de contaminação. Bactérias espirais, movimentos turbilhonais, fluxos num campo de vetores, terreno liso, essências vagas, no qual as “... singularidades se distribuem como outros tantos acidentes" (DELEUZE; GUATTARI, 1997b, p. 33). E, como informou Sabisch (2011), sobre a contaminação como processo geracional em dança, vivemos um processo de abertura dos nossos corpos para alterações qualitativas. No quadro 4 se observam trechos desse diálogo.

Quadro 4: Trechos de "Um diálogo bactéria"

Bactéria Espirila (Bela): As aulas de quarta foram um presente. Tudo ficou por perguntar, ao mesmo tempo em que tudo estava muito claro. A heterogeneidade é gritante, as atividades inteiras, a compreensão imediata?

Bactéria Espiroqueta (Beta): Acho que uma das maiores dificuldades das aulas no CIEJA está na questão da heterogeneidade, mas ao mesmo tempo considero uma das maiores vantagens para mim e para os próprios estudantes.

23Em Mil platôs, Deleuze e Guattari (1997a, 1997b) referem-se a hecceidades nos platôs 10 (livro 4), 12, 14 e 15 (livro 5) e nestes podemos depreender que hecceidades referem-se a processos de individuação sem sujeitos, sem substância, mas composto por intensidades, velocidades, latitudes e longitudes, em alguns momentos como sinônimo de acontecimento. Mas será no platô 10, em uma nota de rodapé, que Deleuze e Guattari (1997a) expõem a origem da palavra: "Acontece de se escrever "ecceidade", derivando a palavra de ecce, eis aqui. É um erro, pois Duns Scot cria a palavra e o conceito a partir de Haec, "esta coisa". Mas é um erro fecundo, porque sugere um modo de individuação que não se confunde precisamente com o de uma coisa ou de um sujeito." (DELEUZE; GUATTARI, 1997a, p. 40)

24 Utilização do vocábulo como palavra remete-se a Larrosa (2018), quando este nos aponta que as palavras são abertas a sentidos, já os conceitos não o são, definem-se justamente na operação de ter um sentido.

25 Espirilos: Bactérias em forma de espiral que apresentam corpo rígido e locomovem-se com a ajuda de flagelos; Espiroquetas: Bactérias em espiral que são mais flexíveis e locomovem-se por contrações citoplasmáticas. https://brasilescola.uol.com.br/biologia/classificacao-das-bacterias.htm 
Bela: O tema mobilidade urbana suscita muitas possibilidades, mas a turma, os corpos para mim, incríveis.

Beta: Nunca havia reparado nos corpos, na verdade nunca me referi a eles como "corpos"...sempre os olhei de outra forma, sujeitos por inteiro, mesmo tentando possibilitar vivências de acordo com as suas possibilidades de movimento dos seus corpos, acho que nunca havia olhado para eles dessa forma...essa expressão que você utilizou me fez pensar muitas coisas.

Bela: Saí de lá com a plena impressão que aqueles corpos eram inexistentes, que na minha leitura seriam mais que invisíveis (escola numa pequena casa ao lado de uma grande rodovia, corpos que se deslocam, muitos, os carnalmente marcados, porque deficientes, em carros tipo van ou poderíamos pensar, caixas opacas que param na frente da escola, uma conquista porque se deslocam, mas como), porque estavam completamente alijados dos processos sociais como os concebemos.

Beta: Gostei da expressão corpos inexistentes...faço uma relação com as vidas desses sujeitos. Para muitas pessoas essas vidas valem menos, afinal, são analfabetos, são velhos, são deficientes, são pobres, são pretos...esses sujeitos carregam tantas marcas que os fazem inexistir para a sociedade. Pensar aulas de Educação Física para esses sujeitos, para quê?

Bela: Com-implicando ... Outro presente a visita ao Memorial da Resistência. Singularidades, tempo, espaço ... A visita ao Memorial da Resistência foi uma aula de como viver singularidades e como tratar o que é comum? O conhecimento sobre a resistência é o que é comum ... Foi deslumbrante ver E, Le, SrC, Lc, V, Lu, T. S, N, J, Pai, Mãe, D, Jc, Prof 1, Prof 2 ... o que no encontro anterior apresentava-se como heterogeneidade transformou-se em singularidade.

Beta: Gostei muito dessa observação. Sempre pensamos nas diferenças, mas nunca notamos o quão singulares são cada um dos sujeitos.

Fonte: Adaptado de Gehres (2019)

E nos encontros-experiências-acontecimentos-diálogos "bactéria", heterogeneidade, singularidades, diferenças, corpos consumidores, corpos políticos, corpos produtores, corpos ocupantes, co-responabilidade, co-implicação foram se produzindo no processo de contaminarem-se mutamente.

$\mathrm{Na}$ segunda performance bactéria, ganhou corpo "Uma bactéria no EJA". Esta constitui-se na intersecção entre dois projetos de pesquisa que se desenvolveram simultaneamente durante ano do 2018, em São Paulo e no Recife. O primeiro, acadêmicocientífico do estágio pós-doutoral a que se refere esse artigo e o segundo, uma pesquisa artística em dança denominada "Projeto Assepsia: o corpo bactéria", o qual acionou as metáforas bactéria e assepsia para questionar as diferentes existências e formas de contaminação nas sociedades contemporâneas.

Da intersecção desses desejos, unindo-se ainda à professora de artes da EJA, surgiu "O CORPO COM O CURRÍCULO CULTURAL DE EDUCAÇÃO FÍSICA: UMA BACTÉRIA NA EJA", que foi realizado no dia 20 de março de 2019. Neste, propôs-se que a bactéria ciliada de Flávia Pinheiro (PINHEIRO, 2019) habitasse a EJA durante uma manhã. A bactéria na EJA propunha processos de descodificação, ainda que sobre excessos de codificação (metáfora, zoomorfizar ${ }^{26}$, habitação)? A segunda

26 Zoomorfizar, tendência a ver características "animais" em humanos, alterar a forma, mas permanecer na representação e na sobrecodificação. 
performance bactéria, encontro-experiência-acontecimento, produziu-se em fotos e palavras (Quadro 5).

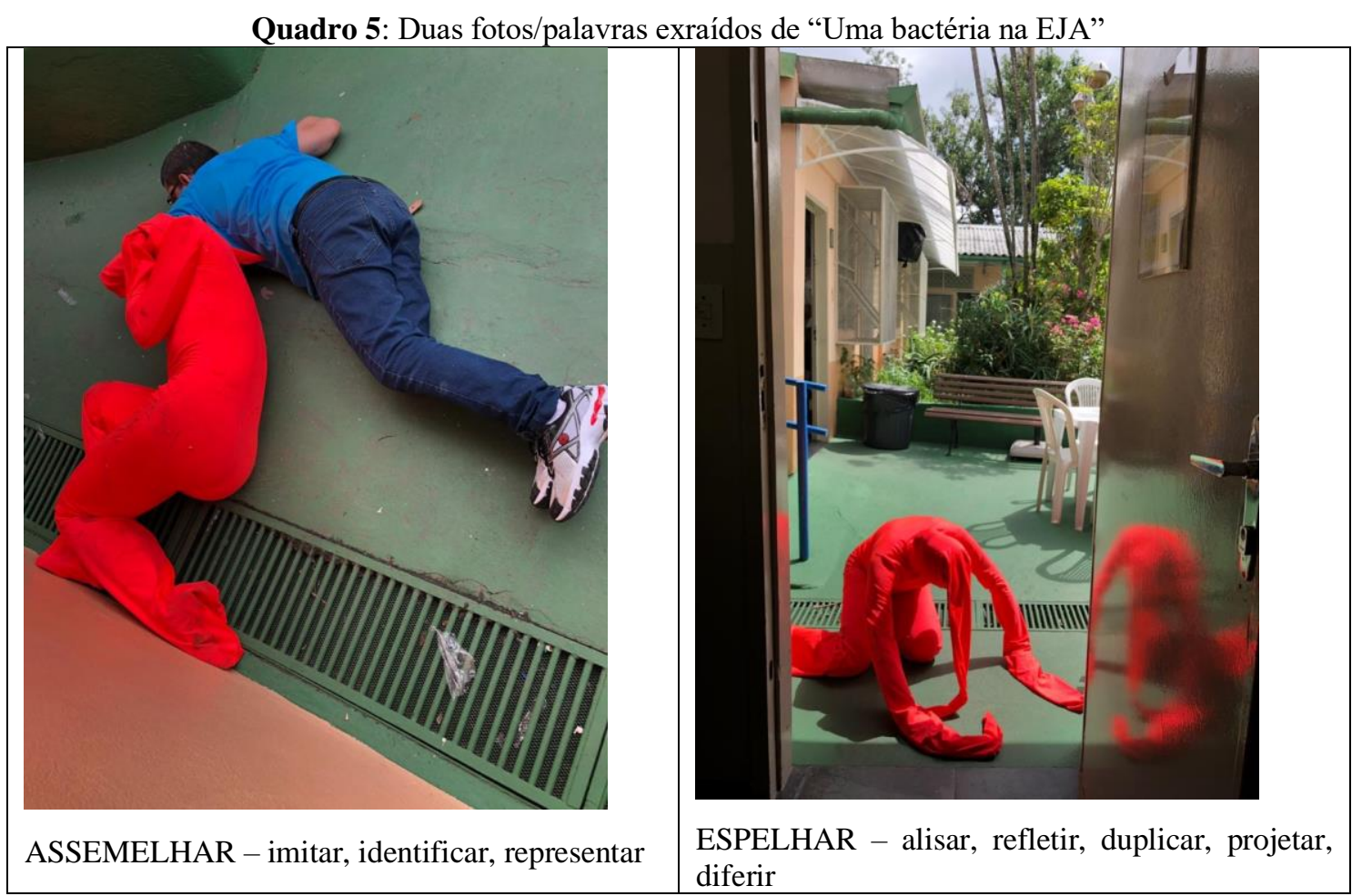

Fonte: Adaptado de Gehres (2019)

Nesse processo, a bactéria instalou-se como ações/imagens: assemelhar (imitar, identificar, representar); posicionar (localizar, estabilizar, estriar); interditar (metrificar, definir, conter); profanar (desativar, desarticular, coisificar); dilatar (respirar, intervalar, comprimir); desativar (excitar, permeabilizar, contaminar); horizontalizar (deslocalizar, esburacar, derivar); espelhar (alisar, refletir, duplicar, projetar, diferir).

A língua da performance transformou-se em sua última atuação, numa criação ficcional, “EJA, uma educação bactéria?”. Esta procurou dar materialidade aos conceitos inventados ao longo da pesquisa, na forma de dois exercícios de criação e uma performance com os corpos da EJA, nas palavras da Beta, dispostos e disponíveis para "experenciar propostas diferentes" ou para diferir de si e se contaminar dos outros e das propostas.

O primeiro exercício consistiu em exercícios de improvisação com a respiração que partem da materialidade corporal (ações concretas) para criar estados que intensificam a percepção corporal. O segundo exercício caracterizou-se como uma improvisação com espelhos (última ação da bactéria ciliada de Flávia Pinheiro) para intensificar as noções de representação, imagem, identidade e transitoriedade. Por fim, a 
performance realizou-se nas ações de respirar e refletir imagens na secretaria, no corredor, na sala da direção, no pátio, na rua em frente à EJA, no restaurante da esquina, no ponto do ônibus, no teatro no dia da entrega dos certificados.

\section{Em debate ...}

Pesquisar com o currículo cultural da Educação Física como pesquisa intervenção, a cartografia, mostrou-se um exercício com muitas faces.

Neste artigo tomamos como objeto o próprio processo da investigação e identificamos três elementos produtores da cartografia como pesquisa intervenção esquizoanalítica:

1- as materialidades das línguas falada e escrita, nos encontros propostos pela investigação, e também na própria pesquisa, ao consubstanciar-se como texto impresso em folha branca bidimensional, nos jogos semânticos e sintáticos da língua portuguesa;

2- a invenção de conceitos como procedimento da própria ação de cartografar, mas não como finalidade, meta, objetivo ou ontologia;

3- a produção de línguas para dar materialidade às invenções de conceitos com os encontros-experiências-acontecimentos, distanciando-nos de qualquer possibilidade de representação e/ou interpretação.

\section{Referências}

BONETTO, P. X. R. A escrita-currículo da perspectiva cultural da Educação Física: por que fazemos o que fazemos? Texto não publicado. 2017. Disponível em http://www.gpef.fe.usp.br/teses/bonetto 03.pdf. Acesso em: 23 mar. 2017.

BORGES, C. C. O.; VIEIRA, R. A. G.; MELO, V. C. Pensar a contemporaneidade de outros modos: contribuições da perspectiva foucaultiana e deleuze-gattariana. Polêmica, Rio de Janeiro, v. 17, n.3, p. 38-59, jul./ago./set. 2017. Disponível em: https://www.e-

publicacoes.uerj.br/index.php/polemica/article/view/31042/21936. Acesso em 30 maio. 2019.

DELEUZE, G.; GUATTARI, F. Mil platôs: capitalismo e esquizofrenia. (Vol. 1). Rio de Janeiro: Ed. 34, 1995a.

DELEUZE, G.; GUATTARI, F. Mil platôs: capitalismo e esquizofrenia. (Vol. 2). Rio de Janeiro: Ed. 34, 1995b.

DELEUZE, G.; GUATTARI, F. Mil platôs: Capitalismo e esquizofrenia. (Vol. 3). Rio de Janeiro: 34, 1996. 
DELEUZE, G.; GUATTARI, F. Mil platôs: capitalismo e esquizofrenia. (Vol. 4). Rio de Janeiro: Ed. 34, 1997a.

DELEUZE, G.; GUATTARI, F. Mil platôs: capitalismo e esquizofrenia. (Vol. 5). Rio de Janeiro: Ed. 34, 1997b.

DELEUZE, G.; GUATTARI, F. Kafka: para uma literatura menor. Lisboa: Assírio \& Alvim, 2003.

GEHRES, A. F. Currículo cultural de Educação Física e a linguagem corporal: uma intervenção/cartografia a partir da dança. 2019. Relatório de Pesquisa (Pós-Doutorado) Universidade de São Paulo, Faculdade de Educação, São Paulo, 2019. Disponível em: http://www.gpef.fe.usp.br/teses/gheres_01.pdf. Acesso em: 10 de fev. 2020.

GEHRES, A. F.; NEIRA, M. G. Exercícios cartográficos com o currículo cultural da Educação Física no Brasil: uma pesquisa intervenção. In: CONGRESSO IBERO-AMERICANO EM INVESTIGAÇÃO QUALITATIVA, 8., 2019, Lisboa. Anais... Aveiro: Ludomedia, 2019. v. 1. p. 691-698. Disponível em:

https://proceedings.ciaiq.org/index.php/CIAIQ2019/article/view/2239. Acesso em: 31 de jan. 2020.

GREINER, C. Fabulações do corpo japonês e seus microativismos. São Paulo: n-1, 2017.

GUATTARI, F.; ROLNIK, S. Micropolítica: cartografias do desejo. 4. ed. Petrópolis: Vozes, 1996.

KATZ, H.; GREINER, C. Por uma teoria do corpomídia. In: GREINER, C. O corpo: pistas para estudos interdisciplinares. 3. ed. São Paulo: Annablume, 2008. p. 125-134.

LAPOUJADE, D. Deleuze: os movimentos aberrantes. São Paulo: n-1, 2015.

LARROSA, J. Nietzsche e a educação. 3. ed. Belo Horizonte: Autêntica, 2009.

LARROSA, J. Pedagogia Profana: danças, piruetas e mascaradas. 5. ed. Belo Horizonte: Autêntica, 2013.

LARROSA, J. Tremores: escritos sobre experiência. 1ed.; 3. reimp. Belo Horizinte: Autêntica, 2018.

LEPECKI, A. Planos de composição: dança, política e movimento. In: RAPOSO, P. et al. (org.). A terra do não-lugar: diálogos entre antropologia e performance. Florianópolis: Editora UFSC, 2013. p.111-122.

NEIRA, M. G. Educação Física. São Paulo: Blucher, 2011. (Coleção A reflexão e a prática no ensino; v. 8).

NEIRA, M. G. Educação Física Cultural: inspiração e prática pedagógica. 2. ed. São Paulo: Paco, 2019.

NEIRA, M. G.; NUNES, M. L. F. Contribuições dos estudos culturais para a Educação Física. Rev. Bras. Ciênc. Esporte, Florianópolis, v. 33, n. 3, p. 671-685, jul./set. 2011 Disponível em: http://www.scielo.br/scielo.php?script=sci arttext\&pid=S0101-32892011000300010. Acesso em: 23 set. 2016 
NUNES, M. L. F. Educação Física na área de linguagens e códigos. In: NEIRA, M. G.; NUNES, M. L. F. (org.). Educação Física cultural: Escritas sobre a prática. Curitiba: CRV, 2016. p. 51-70.

NUNES, M. L. F. Planejando a viagem ao desconhecido: o plano de ensino e o currículo cultural de Educação Física. In: FERNANDES, C. (org.). Ensino Fundamental: planejamento a prática pedagógica. Curitiba: Appris, 2018. p. 77-115.

PASSOS, E.; KASTRUP, V.; ESCÓSSIA, L. (org.). Pistas do método da cartografia: pesquisa-intervenção e produção de subjetividade. Porto Alegre: Sulina, 2015.

PINHEIRO, F. Relatório de projeto de pesquisa de criação - Projeto Assepsia: o corpo bactéria. Texto não publicado. 2019.

RAMOS, L. F. Mimesis performativa: a margem de invenção possível. São Paulo: Annablume, 2015.

RIBEIRO, C. R. O agenciamento Deleuze-Guattari: Considerações sobre método de pesquisa e formação de pesquisadores em educação. Educação Unisinos, São Leopoldo, v. 20, n.1, p. 6875, jan./abr. 2016.

ROMAGNOLI, R. C. O conceito de implicação e a pesquisa-intervenção institucionalista. Psicologia \& Sociedade, Belo Horizonte, v. 26, n. 1, p. 44-52, 2014. Disponível em: http://www.ufrgs.br/seerpsicsoc/ojs2/index.php/seerpsicsoc/article/view/3696/2312. Acesso em: 25 mar. 2016.

SABISCH, P. What can choreography do? In: NIKKANEN, A. et al. The swedish dance history. Stockholm: INPEX, MDT, 2011. p. 82-102.

SANTAELLA, L. O que é semiótica. São Paulo: Brasiliense, 1983. (Coleção Primeiros Passos)

SANTAELLA, L. As linguagens como antídoto ao midiacentrismo. Matrizes, São Paulo, n. 1, p. 75-97, 2007. Disponível em:

https://www.revistas.usp.br/matrizes/article/viewFile/38178/40907. Acesso em: 20 fev. 2017.

TEDESCO, S. H.; VALVIESSE, K. S. P. Linguagem e criação: considerações a partir da pragmática e da filosofia de Bergson. Arquivos Brasileiros de Psicologia, Rio Claro, v. 61, n. 2, p. 1-12, 2009. Disponível em:

http://pepsic.bvsalud.org/scielo.php?script=sci_arttext\&pid=S1809-52672009000200002.

Acesso em: 23 mar. 2017.

Recebido em: 12 de fevereiro de 2020.

Aceito em: 20 de março de 2020. 